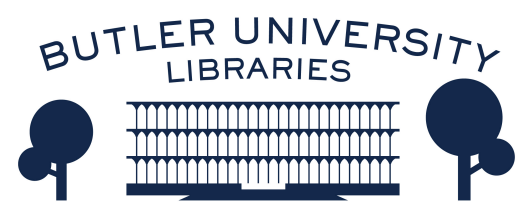

Journal of Hindu-Christian Studies

Volume 19

Article 11

January 2006

\title{
Viewpoint: Dialogues Within Dialogue and Conversations Barely Begun
}

Corinne Dempsey

Follow this and additional works at: https://digitalcommons.butler.edu/jhcs

Part of the Religion Commons

\section{Recommended Citation}

Dempsey, Corinne (2006) "Viewpoint: Dialogues Within Dialogue and Conversations Barely Begun," Journal of Hindu-Christian Studies: Vol. 19, Article 11.

Available at: https://doi.org/10.7825/2164-6279.1366

The Journal of Hindu-Christian Studies is a publication of the Society for Hindu-Christian Studies. The digital version is made available by Digital Commons @ Butler University. For questions about the Journal or the Society, please contact cbauman@butler.edu. For more information about Digital Commons @ Butler University, please contact digitalscholarship@butler.edu. 


\section{VIEWPOINT \\ Dialogues Within Dialogue and \\ Conversations Barely Begun}

\section{Corinne Dempsey \\ University of Wisconsin - Stevens Point}

MY interest in Hindu-Christian studies stems from adventures with two religious traditions that are, in a manner of speaking, "out of place": popular Christian practice in a predominantly Hindu south Indian setting and a Hindu temple within the Christian context of rural upstate New York. In some ways these two Hindu-Christian settings could not be more different. The Kerala Christians with whom I worked claim an ancient and lofty heritage while the upstate New York temple, established in 1998 in a refurbished barn and led by a maverick guru, represents a definitive break from orthopraxy.

As traditions seemingly out of place, both, in spite of their differences, reflect interreligious encounters that are more a matter of cultural collision than overt, premeditated dialogue. Conversations between Hindu and Christian realms often take the form of syncretic practices and philosophies, neighborly resistance and approval, and, when I write about them, my own secondary impositions and analyses. In the spirit of secondary reflection, I take this opportunity to allow these two settings to talk to each other, to offer Hindu-Christian dialogue amid dialogues that is necessarily preliminary yet hopefully offers fodder for further reflection.

In my experience, the starkest similarity between these two contexts is a tug-of-war that is intra- rather than inter-religious, expressed through clashes in motivation between the laity and religious specialists. Countless pilgrims and locals I spoke with at a Catholic saint shrine in Kerala described for me the importance of offering petition or thanksgiving to the saint for health and/or economic blessings. Devotees at the upstate New York temple likewise described how the resident goddess, as source of blessing and healing, draws them in spite of great distances to the town of Rush. Yet religious leaders in both cases often harbored higher hopes for their flock. My research collaborator in Kerala, Sr. Josephina, who normally kept such sentiments private, excitedly interrupted one of my conversations with a cluster of pilgrims to introduce a gentleman who was at the shrine for the "correct" reasons. At her prompting, he repeated what he had told her: that he had made the pilgrimage for inspiration to lead a life of holiness that the saint modeled.

CORNNE DEMPSEY is Associate Professor of Religious Studies at the University of Wisconsin - Stevens Point where she teaches courses on religions of India, popular Catholicism, war and peace in world religions, and political theologies. Her research interests so far have involved popular Christian traditions in south India and diaspora Hinduism in the U.S. Her publications include two books, Kerala Christian Sainthood: Collisions of Culture and Worldview in South India (Oxford University Press, 2001), recipient of the Society of Hindu-Christian Study's Best Book Award 2000-2002, and The Goddess Lives in Upstate New York: Making Home and Breaking Convention at a Hindu Temple in Upstate New York (Oxford University Press, 2006). She co-edited Popular Christianity in India: Riting between the Lines (SUNY Press, 2002) with Selva Raj. Raj and Dempsey are currently co-editing two other volumes on South Asian religions, one on ritual levity and the other on conceptions of the miraculous. 
The temple priest and guru in upstate New York, Aiya, less likely to keep such things to himself, regularly expounds upon his desire to instill a sense of dedication and devotion in visitors who, to his dismay, most often come to the temple for utilitarian purposes.

An interesting ambivalence is worth mentioning. While Sr. Josephina and Aiya wish their respective communities would gather for the "correct" reasons, their religious systems nonetheless support and maintain utilitarian faith. Pilgrims' approach to sacred place and power, cutting across geographical context and religious affiliation, is not surprising considering widely acknowledged reputations for miracles, promoted by respective clergy and religious leaders. If it were not for miraculous power and utilitarian faith, moreover, Sr. Josephina and Aiya would not have much of a flock to shepherd in the correct direction.

A second shared theme, having to do with the status of being "out of place," unearths another layer of ambivalence. Both Kerala Christianity and North American Hinduism struggle with issues of identity and authenticity that, in the contexts I describe, manifest in a mixed relationship with the distant countries and cultures that claim each tradition's center of gravity. For Kerala Christians, particularly Catholics, a reliance on the Christian "West" for institutional authority is complicated by a commonly expressed desire to keep at bay the seemingly omnipresent hedonistic influences of Europe and the U.S. In upstate New York, Aiya often describes his nostalgia for the terrain and traditions of South Asia and for a population less inundated with consumeristic tendencies. At the same time, he admits that only in America could his temple get away with its daily challenge to traditional caste and gender restrictions.

Thus emerges the familiar, often oversimplified, characterization of the West as more materialistically and less spiritually endowed than South Asia. Based on my HinduChristian encounters, however, I find another distinction between South Asia and the U.S. to ring clearer. Turning the Orientialist dichotomy on its head (or at least on its side), rather than associating the U.S. with global influence and infiltration, this distinction associates it instead with popular provincialism.
Kerala's organically generated interreligious dialogue, expressed through ritual exchange and Hindu-Christian syncretic practices on the local level, has no analogy in North America. While lay Keralites are often unavoidably aware of the practices and beliefs of their Hindu and Christian neighbors, the same cannot be said of Hindu-Christian exchange in the U.S. - at least on one side of the equation. At the Rush temple, members from India and Sri Lanka are nearly always familiar with Christian prayers and holy figures, and Aiya's public talks are often peppered with Bible verses. For the exclusively Euro-American neighborhood into which it has moved, however, the temple represents first contact with people outside Christianity or Judaism. This somewhat explains the Rush town council who, responding to the neighborhood's fierce opposition, initially voted down the proposed temple (a.k.a., barn renovation). Today, with rare exceptions, the neighbors keep their distance. Although interreligious exchange is on the rise in the U.S., the lack of popular exchange at Rush reflects, as I understand it, more the rule than the exception.

It bears mentioning that this geographic disparity in Hindu-Christian interchange has much to do with colonialism and time. Christianity has been spread, often forcefully and for centuries, throughout the globe, whereas Hinduism has not. Nonetheless, with Hindu communities now emerging across North America under a completely different set of circumstances, our interreligious awareness has much catching up to do. Although higher education in the U.S. provides a venue for teaching about world religions, the trickle down effect, as is often the case, is not the most effectual. The question is how we, as educators, can affect the popular realm so in need of interreligous understanding. Like Sr. Josephina and Aiya, interdependent with their flock yet concerned (perhaps presumptuously) that they have the "correct" view, we have our work cut out for us. 